\title{
Microstructure of the interface zone after explosive welding and further annealing of A1050/Ni201 clads using various joining conditions
}

\author{
Izabella Kwiecien ${ }^{1, \star}$ (D), Piotr Bobrowski ${ }^{1}$, Marta Janusz-Skuza ${ }^{1}$, Anna Wierzbicka-Miernik ${ }^{1}$, \\ Zygmunt Szulc ${ }^{2}$, and Joanna Wojewoda-Budka ${ }^{1}$ \\ ${ }^{1}$ Institute of Metallurgy and Materials Science, Polish Academy of Sciences, 25 Reymonta St., 30-059 Cracow, Poland \\ ${ }^{2}$ High Energy Technologies Works 'Explomet', 100H Oswiecimska St., 45-641 Opole, Poland
}

Received: 31 October 2019

Accepted: 18 December 2019

Published online:

17 January 2020

(C) The Author(s) 2020

\begin{abstract}
Explosive welding is a joining method suitable for materials difficult or impossible to connect using traditional welding techniques. In this work, the microstructure details occurring in the neighborhood of the aluminum (A1050) and nickel (Ni201) alloys' interfaces in explosive welds were described. It was shown that using appropriate welding conditions, although the mutual localization of the colliding plates was different, the microstructure of the bonded zone did not change. Moreover, further annealing of the samples at $500{ }^{\circ} \mathrm{C}$ revealed the microstructure transformation occurring as a result of the diffusion phenomena. This in turn provides the details essential in proper designing of the multilayers of metallic-intermetallic $\mathrm{Al} / \mathrm{Ni}$ composites.
\end{abstract}

\section{Introduction}

A combination of alloys such as aluminum (A1050) and nickel (Ni201) has a large practical application in many branches of industry. However, our attention has been directed toward the application, where they are acting as the interlayers or they are forming metallic-intermetallic layered composite materials. Explosive welding (EXW) is increasingly popular as it allows joining materials difficult or impossible to connect using traditional techniques, e.g., with large difference of melting points such as $\mathrm{Ti} / \mathrm{Al}, \mathrm{Al} / \mathrm{Cu}$, $\mathrm{Ti} /$ steel, $\mathrm{Cu}$ /steel or $\mathrm{Al} /$ steel [1-7]. During EXW, as a result of collision of the flyer plate (fp) with the base plate (bp), the stable bond is obtained. This collision excludes the presence of impurities or oxides located on the surfaces of joined materials; however, it also causes strong plastic deformation of joined sheets close to their interface; and this phenomenon involves not only plates and sheets but also round bars and tubes [8-10]. Many works describe the influence of the different parameters on the EXW joining technique; for example, the effect of the standoff distance between the colliding plates was investigated by Prażmowski et al. [11] and Acarer et al. [12]. Acarer et al. [12] studied the changes at the interfaces formed between steel plates with various hardnesses in relation to explosive rate, stand-off

Address correspondence to E-mail: i.kwiecien@imim.pl 
distance and anvil, which were applied. They showed that the microhardness increased close to the welding interface as a result of excess of plastic deformation in the explosive area and their findings were consistent with the previous works [13-16]. The interface areas consisted of the fine-grained structure in contrast to areas far from them. Moreover, the authors indicated that the increase in the stand-off and explosive loading distance resulted in the wave structure at the interface [12]. The effect of the various detonation rates on the interface was indicated also by Kahraman et al., who investigated titanium/ stainless steel clads. They confirmed that when the low explosive loads were used, the interface was flat, and on the other hand, with the application of higher explosive loads, the wavy interface was observed [7]. To our best knowledge, only a few papers have discussed the $\mathrm{Al} / \mathrm{Ni}$ explosive welds in detail [17-19]. Gerland et al. [17] indicated the possibility of joining of the thin Ni films with $\mathrm{Al}$ alloy by EXW technique. They investigated the interaction of a flyer plate in the form of the Ni thin film of 50 and $100 \mu \mathrm{m}$ thickness with AU4G (Al alloy) base plate. In their paper, a brief description was given, regarding the explosion velocity influence on the interface microstructure (character of interface, amount of intermetallics or damages such as cracks) and roughness of the film surface. Two other works $[18,19]$ dealt with $\mathrm{Al} / \mathrm{Ni}$ multilayered composites manufactured with $4200 \mathrm{~m} \mathrm{~s}^{-1}$. These studies focused on the microstructure of interfaces and their changes resulting from their annealing at $620^{\circ} \mathrm{C}$. In particular, Ogneva et al. [18] indicated the existence of two types of interfaces: $\mathrm{Ni} / \mathrm{Al}$ and $\mathrm{Al} / \mathrm{Ni}$, which, in regard to their mutual location, differed in shape and amount of the melted region thickness. The $\mathrm{Ni} / \mathrm{Al}$ interfaces were flat, while $\mathrm{Al} / \mathrm{Ni}$ were characterized by periodic variation of the mixing zones. These differences had further implication, when the material was annealed, evidencing various intermetallics' growth velocities at these two types of interfaces.

In respect to previous works about EXW of $\mathrm{Al} / \mathrm{Ni}$ system, the current paper demonstrates how the interface develops with respect to the various localizations of the colliding plates (aluminum alloy acts either as a flyer plate or base plate). The authors of previous reports $[18,19]$ concluded that the influence of the arrangement of the colliding plates is not significant; however, the discrepancies regarding the localization of the plates could be noticed as can be seen in figure in the work [18]. A similar observation was made by Fronczek et al. [1, 20], where Ti Gr.2 and Al 1050 were explosively welded. In their earlier work (published in 2016), only bimetal consisting of Ti/Al system was studied and wavy interface occurred between the colliding plates [1]. However, later in 2017 the same authors considered three-layered EXW clads prepared from the same materials and with the same detonation velocity (1900-1950 $\mathrm{m} \mathrm{s}^{-1}$ ) in the following configuration: A1050/TiGr.2/A1050. In this case, two types of interface were observed: wavy between A1050/TiGr.2 and flat one between TiGr.2/A1050. The authors explained the formation of flat interface as a result of damping of the impact force by TiGr.2, thereby reducing impact power with the lower A1050 plate [20]. An approach associated with multilayered EXW systems is very interesting and important from an industrial point of view, but did not get unambiguous and basic answer on the influence of arrangement of the plates regarding $\mathrm{Al} / \mathrm{Ni}$ system.

As the strong differences occurring due to the mutual location of the $\mathrm{Al}$ and $\mathrm{Ni}$ alloy plates can be a significant problem during further production formation of the final product, the goal of this study was to obtain welds, where this factor was excluded. Therefore, this study is dedicated to the exposition of any differences occurring in the neighborhood of the interfaces of the A1050/Ni201 welds after explosive welding with respect to the location of the $\mathrm{Al}$ and $\mathrm{Ni}$ alloys. The experiment involved the simple arrangement of two alloys' sheets, where either $\mathrm{Al}$ or Ni alloy were used as a flyer plate joined with a base plate under the same detonation velocity was performed. Proposed approach allowed to expose any microstructural differences between $\mathrm{Al} / \mathrm{Ni}$ and $\mathrm{Ni}$ / $\mathrm{Al}$ welds and their consequences regarding thermal treatment of both types of joints.

\section{Materials and methods}

The studied clads were manufactured from A1050 aluminum alloy (further referred to as $\mathrm{Al}$ ) and 201 nickel alloy (further referred to as $\mathrm{Ni}$ ) sheets of $150 \times 300 \mathrm{~mm}$ dimensions and thickness of $1 \mathrm{~mm}$ for both of them in parallel system. As it was mentioned before, two types of components' arrangements were prepared: (1) Ni used as a flyer plate and $\mathrm{Al}$ as a base plate (noted as $\mathrm{Ni} / \mathrm{Al}$ ) and (2) $\mathrm{Al}$ used as a flyer plate with $\mathrm{Ni}$ as a base plate (noted as $\mathrm{Al} / \mathrm{Ni}$ ). The 
scheme of the mutual localization of the colliding plates is shown in Fig. 1a, b. The same detonation velocity of $2400 \mathrm{~m} \mathrm{~s}^{-1}$ was applied in both these cases. Two factors constituted the variables: the mutual localization of applied plates and the standoff distance between A1050 and Ni201. In the case of $\mathrm{Al} / \mathrm{Ni}$, the initial stand-off distance was doubled $(2 \mathrm{~h})$ in comparison with the $\mathrm{Ni} / \mathrm{Al}$ case $(1 \mathrm{~h})$. Samples in the size of $15 \times 7 \times 2 \mathrm{~mm}$ were cut from the middle part of the explosively welded plates. The cross sections of the samples after EXW were prepared by standard metallographic procedure: grinding on abrasive $(\mathrm{SiC})$ papers and polishing, first with $3 \mu \mathrm{m}$ diamond paste, and then with $0.04 \mu \mathrm{m}$ colloidal silica suspension.

Microstructure and chemical composition were examined by means of the scanning electron microscope (SEM) FEI Quanta FEG equipped with EDAX Apollo Energy Dispersive X-ray Spectrometer (EDS). Additionally, the electron backscattered diffraction (EBSD, EDAX Hikari) technique was applied to reveal the differences of grains' size and shape of the flyer and base plate as well as the interface zone after annealing process. The observations in the nanoscale were conducted using transmission electron microscopy (TEM, Tecnai G2, FEI). The thin foil to the TEM analysis was prepared by the focus ion beam (FIB, Quanta 2D, FEI) technique.

\section{Results and discussion}

SEM-EBSD maps (Fig. 2) collected from the initial materials revealed the equiaxed grains of the nickel (Fig. 2a) with the average size of $21.8 \mu \mathrm{m}$ and elongated grains of aluminum (Fig. $2 \mathrm{~b}$ ). Both materials indicated the lack of the crystallographic texture. Some grains of the nickel alloy possessed twin orientation, while the grains of the aluminum were characterized by a typical rolled structure. The same materials were used, to prepare both kinds of clads; it means that the initial state of the colliding plats was identical in any case, as it is shown in Fig. 2.

The examination of the explosively welded clads has been performed to reveal the microstructure of the $\mathrm{Ni} / \mathrm{Al}$ and $\mathrm{Al} / \mathrm{Ni}$ cross sections in the neighborhood of the bonded zone (Fig. 3). For convenience in comparison with the images, one of them (Fig. 3b) was rotated around the horizontal axis. Therefore, the Ni201 is located on the top in both images. The first difference to be mentioned is related to the thickness changes of Ni201 after explosion being $1150 \mu \mathrm{m}(\mathrm{Ni} /$ $\mathrm{Al})$ or $1108 \mu \mathrm{m}(\mathrm{Al} / \mathrm{Ni})$, while A1050 is about $937 \mu \mathrm{m}$ $(\mathrm{Ni} / \mathrm{Al})$ and $895 \mu \mathrm{m}(\mathrm{Al} / \mathrm{Ni})$. (The initial thickness of both plates was $1 \mathrm{~mm}$.) The final thickness of plates may change, as a result of strong plastic deformation of alloys during EXW. The differences in the thickness of plates between $\mathrm{Ni} / \mathrm{Al}$ and $\mathrm{Al} / \mathrm{Ni}$ can be also associated with the stand-off distance that is not equal for these two cases, as it is twice larger for $\mathrm{Al} /$ $\mathrm{Ni}$ clad. Generally, higher stand-off distance between plates yields longer acceleration path of the flyer plate upon detonation, which leads to higher impact velocity and energy of the process [11]. Applied detonation velocity of $2400 \mathrm{~m} \mathrm{~s}^{-1}$ resulted in the formation of the wavy interface for both types of explosive welds, which is different in comparison with the observations described in work [20] by Bataev et al., where the detonation velocity was much higher $\left(4200 \mathrm{~m} \mathrm{~s}^{-1}\right)$. The average distances between waves are similar for $\mathrm{Ni} / \mathrm{Al}$ and $\mathrm{Al} / \mathrm{Ni}$ samples, being $329 \mu \mathrm{m}$ and $318 \mu \mathrm{m}$, respectively. The most striking difference is related to the amount of melted regions and shape of the waves, which will be discussed later. During the EXW, high velocity impact generates high stress and high energy in the neighborhood of the collision point and causes local melting and plastic deformation of welded alloys [21, 22]. Crosland et al. [13] indicated that the kinetic energy from explosion is transformed to heat energy, which leads to the local melting at the collision point and crystallization of the intermetallic phases in this region [13]. The EBSD maps (Fig. 3c, d) were
Figure 1 Schemes of the experimental setups: a Ni201(fp)/A1050(bp) and b A1050 (fp)/Ni201 (bp), $h$ applied stand-off distance. (a)

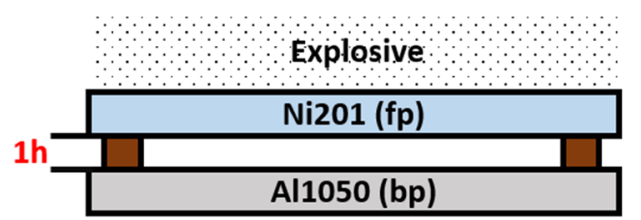

(b)

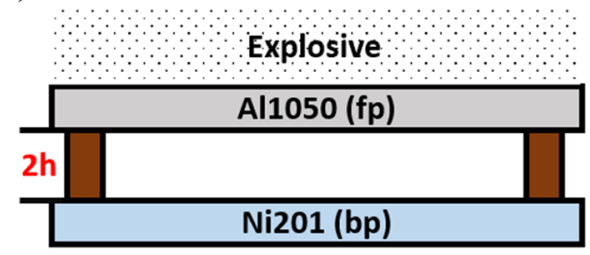


Figure 2 Electron backscattered diffraction (EBSD) maps of initial plates before the explosive welding: a Ni201 and b A1050 alloys.
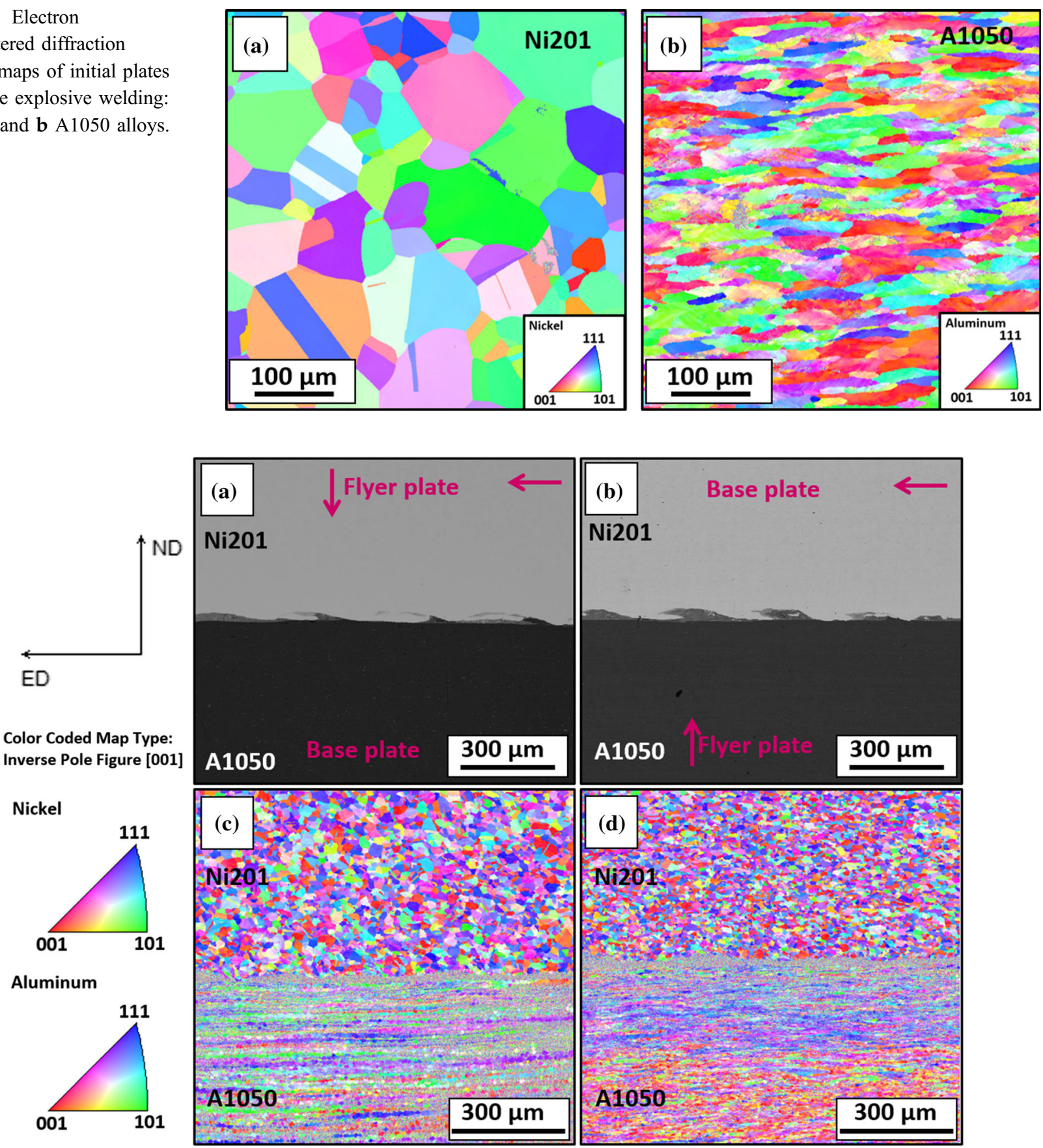

Figure 3 Comparison of the interface microstructure of Ni/Al (a, c) and Al/Ni (b, d) after EXW (on the top SEM/BSE images, on the bottom SEM/EBSD maps).

collected under low magnification in order to follow the general microstructure changes of the joined materials far and close to their interface. Ni201 plate is composed of equiaxed grains throughout the overall cross section in both cases; nevertheless, the mean size of the grain is different for each of them reaching $9 \mu \mathrm{m}$ for $\mathrm{Ni} / \mathrm{Al}$ and $6.8 \mu \mathrm{m}$ for $\mathrm{Al} / \mathrm{Ni}$.
Although the time of heat transfer is very short and increase in alloys' overall temperature is slight [23], the observed grain size changes between both variants of clads could be associated with different thermal conductivities of alloys: A1050 $\left(\sim 200 \mathrm{~W}\left(\mathrm{~m} \mathrm{~K}^{-1}\right)\right.$ and $\mathrm{Ni201}\left(\sim 90.7 \mathrm{~W}\left(\mathrm{~m} \mathrm{~K}^{-1}\right)\right.$. When A1050 acts as a flyer plate, the cooling rate is 
higher and the resulting grain size is smaller. Additionally, in the case of $\mathrm{Al} / \mathrm{Ni}$ weld, the initial standoff distance is higher, and this is directly related to the energy/stress near the collision point. Therefore, in close vicinity of the interface zone, the refinement of $\mathrm{Ni}$ grains is stronger and more pronounced in comparison with $\mathrm{Ni} / \mathrm{Al}$ interface. On the other hand, the bands of the aluminum alloy grains formed a typical rolled microstructure.

The melted regions formed in $\mathrm{Ni} / \mathrm{Al}$ welds are elongated, slender, thinly finished (Figs. 3a, 4d) in opposition with the ones in $\mathrm{Al} / \mathrm{Ni}$ welds, being more massive, sharply finished with irregular shapes (Figs. 3b, 4c). Within the melted areas of both types of welds, the nickel islands were enclosed inside (Fig. 4a, c) together with the dendritic microstructure formed due to the crystallization from a liquid state (Fig. 4f, h). For $\mathrm{Al} / \mathrm{Ni}$ welds, the whirls of heterogeneous chemical composition (Fig. 4h) were also noticed, while for $\mathrm{Ni} / \mathrm{Al}$ welds, the dark contrast structure, presented in Fig. $4 \mathrm{~d}$, e, was characteristic. Single cracks, going across whole thickness or just through parts of the melted regions (Fig. 4c), were also present. Ogneva et al. [19] observed a continuous mixing zone of two types: wavy $\mathrm{Al} / \mathrm{Ni}$ and nearly flat $\mathrm{Ni} / \mathrm{Al}$, depending on the localization of the interface inside the multilayered $\mathrm{Al} / \mathrm{Ni}$ composite. This observation is inconsistent with the presented work, where arrangement of the colliding plates always led to the wavy nature of the area of joining; however, these waves were significantly broader, when the aluminum alloy acted as a flyer plate. Nevertheless, the same microstructure components inside the waves such as fine dendrites or vortex were observed as in $[18,19]$. Chemical composition measurements confirmed that the melted zones were not homogeneous and consisted of a mixture of $\mathrm{Al}$ and $\mathrm{Ni}$ with various concentrations of these elements; however, the analytical resolution of EDS in SEM is insufficient for fine-grained regions as well as the swirled ones and for revealing the type of possible intermetallic phases existing in the melted regions.

SEM-EDS measurements (Fig. 5) showed that during the explosion strong mixing of elements occurs (Fig. 5b, c, e, f); therefore, inside them various phases were observed: $\mathrm{Al}_{3} \mathrm{Ni}$ and $\mathrm{AlNi}$ (for $\mathrm{Ni} / \mathrm{Al}$ weld) and $\mathrm{Al}_{3} \mathrm{Ni}_{2}$ (for $\mathrm{Al} / \mathrm{Ni}$ ). In both cases the eutectic mixture of $(\mathrm{Al})+\mathrm{Al}_{3} \mathrm{Ni}$ was identified. Moreover, as it was mentioned above closed islands of either aluminum or nickel inside the mixing zones were observed (Fig. 5a, d). The chemical compositions of the detected phases are collected in Table 1; numbers 1-4 correspond with the yellow points in the BSE-SEM images (Fig. 5a, d).

The BSE-SEM observations of the $\mathrm{Ni} / \mathrm{Al}$ clad interface revealed characteristic microstructure consisting of dark contrast and oval precipitates surrounded by the brighter matrix (Fig. 4e). Interesting is that this kind of microstructure was not detected in other works describing $\mathrm{Al} / \mathrm{Ni}$ explosive welding clads [17-19]. However, these works were associated with different types of $\mathrm{Ni} / \mathrm{Al}$ EXW systems
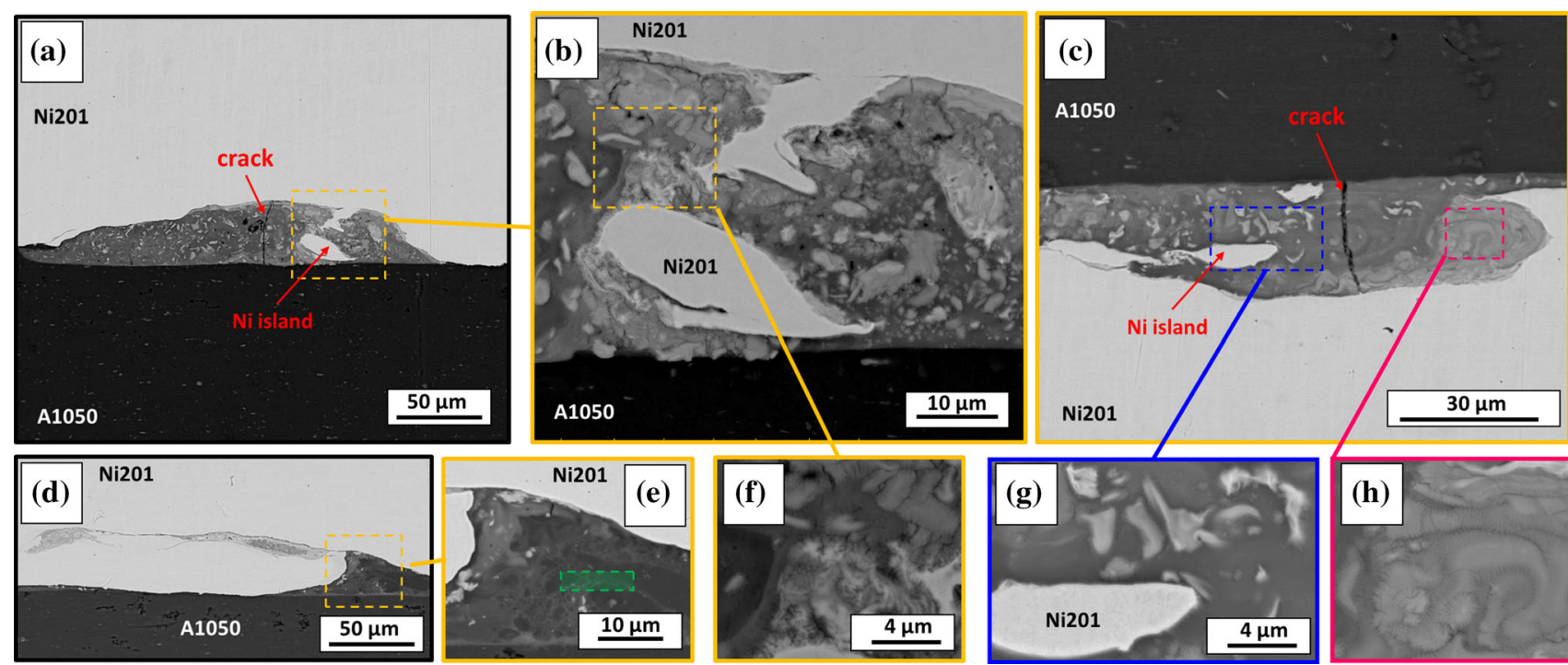

Figure 4 Microstructure of the melted regions located at the $\mathrm{Ni} / \mathrm{Al}(\mathbf{a}, \mathbf{b}, \mathbf{d}, \mathbf{e}, \mathbf{f})$ and $\mathrm{Al} / \mathrm{Ni}(\mathbf{c}, \mathbf{g}, \mathbf{h})$ interfaces. 

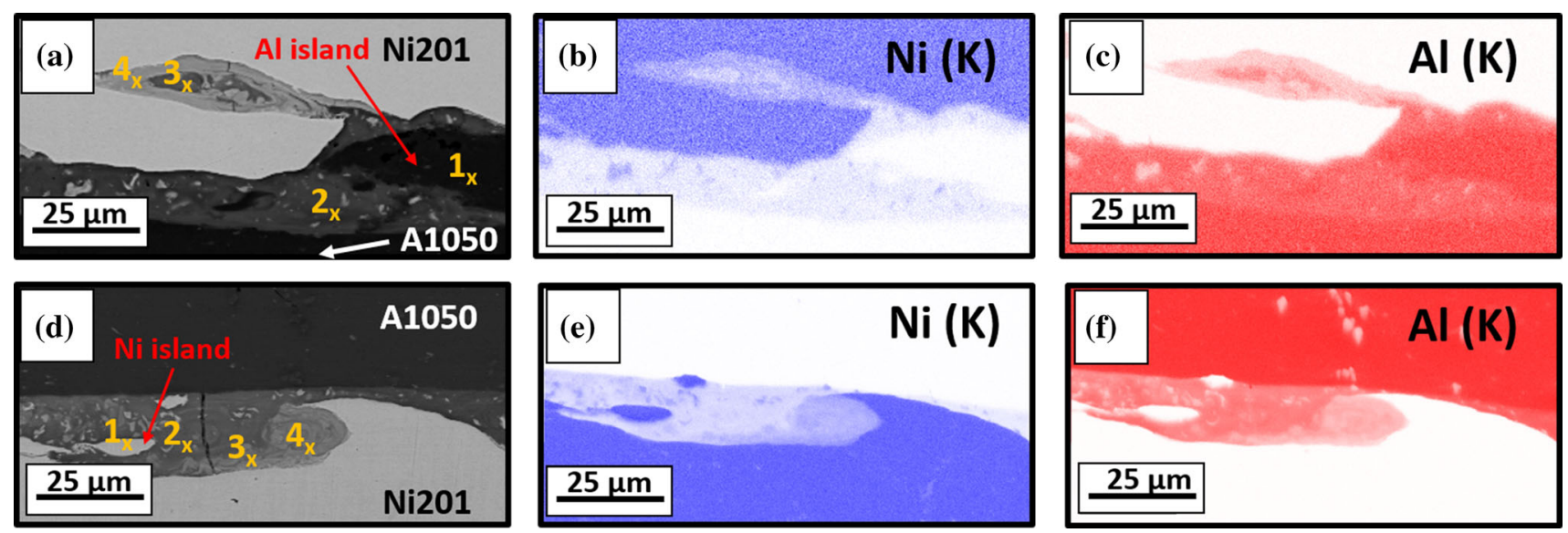

Figure 5 SEM-BSE microstructures of the melted regions with marked points of chemical analysis (a, d) and corresponding EDS maps of element distribution for $\mathrm{Ni} / \mathrm{Al}(\mathbf{b}, \mathbf{c})$ and $\mathrm{Al} / \mathrm{Ni}(\mathbf{e}, \mathbf{f})$ interface zones.

Table 1 The chemical compositions obtained with the aid of EDS in SEM

\begin{tabular}{|c|c|c|c|c|c|c|}
\hline & \multirow{2}{*}{$\begin{array}{l}\text { Analysis } \\
\text { Phase }\end{array}$} & \multicolumn{2}{|l|}{$\mathrm{Ni} / \mathrm{Al}$} & \multirow[t]{2}{*}{ Phase } & \multicolumn{2}{|l|}{$\mathrm{Al} / \mathrm{Ni}$} \\
\hline & & \multicolumn{2}{|c|}{ Content at. $\%$} & & Content at.\% & $\mathrm{Al}$ \\
\hline 1. & $\mathrm{Al}$ & $0.3 \pm 0.3$ & $99.7 \pm 2.0$ & $\mathrm{Ni}$ & $99.4 \pm 2.0$ & $0.6 \pm 0.3$ \\
\hline 2. & $(\mathrm{Al})+\mathrm{Al}_{3} \mathrm{Ni}$ & $10.5 \pm 0.2$ & $89.5 \pm 1.8$ & $(\mathrm{Al})+\mathrm{Al}_{3} \mathrm{Ni}$ & $14.7 \pm 0.6$ & $85.3 \pm 1.7$ \\
\hline 3. & $\mathrm{Al}_{3} \mathrm{Ni}$ & $25.1 \pm 0.5$ & $74.9 \pm 1.5$ & $\mathrm{Al}_{2} \mathrm{Ni}_{3}$ & $32.5 \pm 0.7$ & $67.5 \pm 1.2$ \\
\hline 4. & $\mathrm{AlNi}$ & $52.7 \pm 1.1$ & $47.3 \pm 1.1$ & $\mathrm{Al}_{2} \mathrm{Ni}_{3}$ & $34.0 \pm 0.7$ & $66.0 \pm 1.2$ \\
\hline
\end{tabular}

Numbers 1-4 are marked in Fig. 5a, d (multilayer in contrast to our bimetal) and therefore used detonation velocity, was significantly different $[18,19]$. This region was selected for further examination by means of TEM technique. The thin foil was prepared from the location marked with a green frame in Fig. 4e. The bright-field image (Fig. 6a) revealed a complex structure consisting of the grains of different sizes. Clusters of very fine grains were surrounded by oval precipitations of larger size. Electron diffractions pointed out the AlNi phase within the clusters (Fig. 6b), while the oval precipitates occurred to be aluminum (Fig. 6c). This phase recognition was also confirmed by EDS measurements located in points marked in Fig. 6e, f. Each point corresponds with the data collected in Table 2. Concentration of aluminum inside the clusters of small precipitates (Fig. 6f) is in the range of 43.2-52.8 at.\%, and inside of oval precipitates is equal to 99.9 at.\% (Fig. 6e). In Fig. 6g, maps of the elements' distributions are presented. As it is shown, besides aluminum and nickel, the presence of iron was detected (yellow frame). A trace amount of elements such as $\mathrm{Fe}, \mathrm{Si}$ or $\mathrm{Mn}$ comes from the initial alloys
(A1050 and Ni201), while the copper presence is associated with the applied thin foil holder. What is interesting, the EDS measurements allowed to observe a phase mixture constituting a matrix, which according to the phase equilibrium diagram falls within the $(\mathrm{Al})+\mathrm{Al}_{3} \mathrm{Ni}$ eutectics. In contrast to present work, Bataev et al. [19] used also TEM technique to observe the interfaces formed in multilayered $\mathrm{Ni}$ / $\mathrm{Al}$ composites. In their study, the collected electron diffraction patterns pointed out the presence of metastable $\mathrm{Al}_{9} \mathrm{Ni}_{2}$ phase irregularly distributed within the mixing zone. Nevertheless, it has to be emphasized that Bataev group used almost twice higher detonation velocity. Both Bataev et al. [19] and the current work show the presence of the AlNi phase inside of the mixing zone.

Annealing of both types of welds for a relatively long time of $168 \mathrm{~h}$ at $500{ }^{\circ} \mathrm{C}$ was performed in order to observe the transformation of the interface zone microstructure (Fig. 7). The heat treatment resulted in a significant expansion of the reaction zone and formation of two thick layers of different contrasts. They were identified as $\mathrm{Al}_{3} \mathrm{Ni}(24.0 \pm 0.5$ at.\% of $\mathrm{Ni}$, 



Figure 6 TEM results of the $\mathrm{Ni} / \mathrm{Al}$ interface extracted from the area marked with green frame in Fig. 4e. Bright-field image representing the overall view of microstructure (a) together with selected electron diffraction patterns obtained from clusters of

AlNi precipitates (b) and oval $\mathrm{Al}$ (c) with the corresponding bright-field images. Confirmation of results collected by diffraction pattern by EDS measurements in TEM $(\mathbf{d}-\mathbf{g})$. Points $1-5$ in the images $(\mathbf{e}, \mathbf{f})$ correspond with data collected in Table 2.

Table 2 The chemical compositions obtained with EDS in TEM corresponding with numbers $1-5$ in Fig. 6e, $\mathrm{f}$

\begin{tabular}{|c|c|c|c|c|c|c|}
\hline \multirow[t]{3}{*}{ Point } & \multirow{3}{*}{$\begin{array}{l}\text { Analysis } \\
\text { Phase }\end{array}$} & \multicolumn{2}{|c|}{1 (Fig. 6e) } & \multirow[t]{3}{*}{ Phase } & \multicolumn{2}{|c|}{2 (Fig. 6f) } \\
\hline & & $\mathrm{Ni}$ & $\mathrm{Al}$ & & $\mathrm{Ni}$ & $\mathrm{Al}$ \\
\hline & & \multicolumn{2}{|c|}{ Content at. $\%$} & & \multicolumn{2}{|c|}{ Content at. $\%$} \\
\hline 1. & $(\mathrm{Al})+\mathrm{Al}_{3} \mathrm{Ni}$ & 6.0 & 94.0 & $\mathrm{AlNi}$ & 54.2 & 45.8 \\
\hline 2. & $(\mathrm{Al})+\mathrm{Al}_{3} \mathrm{Ni}$ & 9.2 & 90.8 & AlNi & 47.2 & 52.8 \\
\hline 3. & $\mathrm{Al}$ & 0.1 & 99.9 & AlNi & 56.8 & 43.2 \\
\hline 4. & $\mathrm{Al}$ & 0.2 & 99.8 & $(\mathrm{Al})+\mathrm{Al}_{3} \mathrm{Ni}$ & 89.3 & 10.7 \\
\hline 5. & $\mathrm{Al}$ & 0.1 & 99.9 & $(\mathrm{Al})+\mathrm{Al}_{3} \mathrm{Ni}$ & 85.0 & 15.0 \\
\hline
\end{tabular}


$76.0 \pm 1.5$ at. $\%$ of $\mathrm{Al})$ and $\mathrm{Al}_{2} \mathrm{Ni}_{3}(61.4 \pm 1.2$ at. $\%$ of $\mathrm{Ni}, 38.6 \pm 0.8$ at.\% of $\mathrm{Al})$. The thickness of both phases was similar, when comparing both types of welds, reaching the values of $\mathrm{Al}_{3} \mathrm{Ni}-14 \mu \mathrm{m}$ and $\mathrm{Al}_{3} \mathrm{Ni}_{2}-108 \mu \mathrm{m}$ in $\mathrm{Ni} / \mathrm{Al}$ weld; $\mathrm{Al}_{3} \mathrm{Ni}-22 \mu \mathrm{m}$ and $\mathrm{Al}_{3} \mathrm{Ni}_{2}-105 \mu \mathrm{m}$ in $\mathrm{Al} / \mathrm{Ni}$ weld. As it can be seen in Fig. 7 , the interface between $\mathrm{Ni} 201$ and $\mathrm{Al}_{3} \mathrm{Ni}_{2}$ phase is approximately planar with only local perturbations in both weld types. However, a completely different appearance of phase boundary can be noticed between $\mathrm{Al}_{3} \mathrm{Ni}_{2}$ and $\mathrm{Al}_{3} \mathrm{Ni}$ phases. The interface is irregular and porous, and the layer of $\mathrm{Al}_{3} \mathrm{Ni}$ is thinner but nearly continuous along the entire length of the interface. Short discontinuities of up to $20 \mu \mathrm{m}$ for $\mathrm{Ni} / \mathrm{Al}$ and up to $100 \mu \mathrm{m}$ for $\mathrm{Al} / \mathrm{Ni}$ are rare. Inside the $\mathrm{Al}_{3} \mathrm{Ni}$ phase, the cracks were observed, and areas, where the $\mathrm{Al}_{3} \mathrm{Ni}$ phase is absent, are porous. Observations under higher magnification revealed the presence of the third phase located between $\mathrm{Al}_{3} \mathrm{Ni}$ and A1050. It was additionally enriched in iron, coming from the applied aluminum alloy. The composition of the third phase was found to be $4.0 \pm 0.4$ at. $\%$ of $\mathrm{Fe}, 13.4 \pm 0.5$ at. $\%$ of $\mathrm{Ni}$, $82.6 \pm 1.7$ at. $\%$ of $\mathrm{Al}$. This phase possessed irregular morphology, and it was also located within A1050 in the proximity of the interface region taking the form of numerous small islands with different shapes (Fig. 7a, b). The presence of these islands is independent of the presence of $\mathrm{Al}_{3} \mathrm{Ni}$ phase. The above results are consistent with previous works about $\mathrm{Al} /$ $\mathrm{Ni}$ explosive welding $[18,19]$. Independently on the applied annealing temperature of $500{ }^{\circ} \mathrm{C}$ or $620^{\circ} \mathrm{C}$ used in current work and by Batev group [18, 19], respectively, the $\mathrm{Al}_{3} \mathrm{Ni}$ and $\mathrm{Al}_{3} \mathrm{Ni}_{2}$ phases were formed. The authors of earlier works presented results for the relatively short time of annealing in the range of $5 \mathrm{~min}$ to $5 \mathrm{~h}$ in comparison with the present paper, where the annealing time was $168 \mathrm{~h}$. It is possible that longer annealing time is necessary to form previously mentioned third phase, enriched in iron (consisting of $4.0 \pm 0.4$ at.\% of $\mathrm{Fe}$, $13.4 \pm 0.5$ at. $\%$ of $\mathrm{Ni}, 82.6 \pm 1.7$ at. $\%$ of $\mathrm{Al}$ ), which was not found by Bataev et al. after short time of heat treatment. Other explanations for the presence of the third phase may be associated with different annealing temperatures, which were used by the authors. All researchers used $\mathrm{Al}$ alloy plates with the addition of small amount of iron being about of
Figure 7 Interface zone after annealing at $500{ }^{\circ} \mathrm{C}$ for $168 \mathrm{~h}$ in $\mathrm{Ni} / \mathrm{Al}$ (a) and $\mathrm{Al} / \mathrm{Ni}$

(b) explosively welded clads together with the corresponding EBSD maps of the interface zone of $\mathrm{Ni} / \mathrm{Al}$ (c) and $\mathrm{Al} / \mathrm{Ni}(\mathbf{d})$.
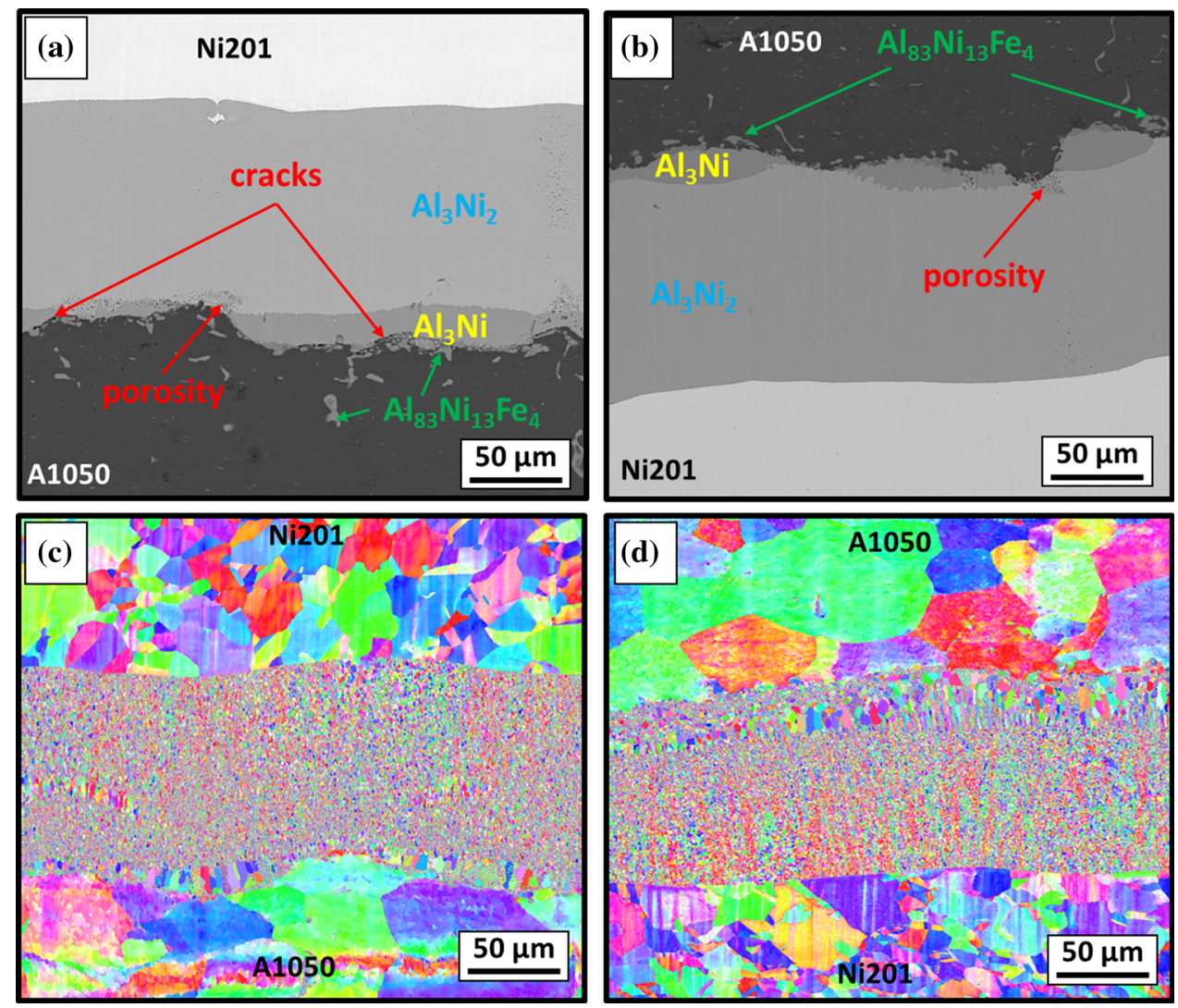
$0.3 \mathrm{wt} \%[18,19]$. Further examination using TEM is essential to determine the crystallography of the phase enriched in iron. The EBSD maps collected for the annealed samples (Fig. 7c, d) show that, as a result of annealing, the grain size of the nickel is similar in both kinds of clads and it reaches $6 \mu \mathrm{m}$ for $\mathrm{Ni} / \mathrm{Al}$ and $4 \mu \mathrm{m}$ for $\mathrm{Al} / \mathrm{Ni}$. In the case of aluminum, determination of grain size from the presented EBSD maps is difficult because grains are relatively large compared to the presented areas. To obtain reliable results, it is necessary to collect EBSD maps from larger area for better statistics. The difference in nickel grains size could be associated with the fact that the calculations were conducted on the relatively small area and some grains (edge grains) cannot be taken into account. Zones corresponding to the $\mathrm{Al}_{3} \mathrm{Ni}_{2}$ and $\mathrm{Al}_{3} \mathrm{Ni}$ phases are weakly indexed.

\section{Conclusions}

This study reports the microstructure analysis of the explosively welded clads with particular attention to the interface region. The mutual arrangement of the colliding clads was alternated in order to follow the consequences of this parameter change. The microstructure of $\mathrm{Ni} / \mathrm{Al}$ and $\mathrm{Al} / \mathrm{Ni}$ welds in the after EXW state was similar, and only slight differences of the waves' appearance were observed; however, within the mixing zones of both types of samples, the same morphologies were noted such as metallic islands, dendritic microstructure or small particles enriched in $\mathrm{Ni}$ within aluminum-rich matrix. Based on the SEM-EDS measurements, phases such as $\mathrm{Al}_{3} \mathrm{Ni}, \mathrm{Al}_{3} \mathrm{Ni}_{2}$ and $\mathrm{AlNi}$ were identified, together with the $(\mathrm{Al})+\mathrm{Al}_{3} \mathrm{Ni}$ eutectics. Beside them, the islands of aluminum and nickel were also observed. The electron diffraction and EDS measurements in TEM allowed to confirm the presence of clusters of AlNi phase, surrounded by the eutectic mixture (Al) $+\mathrm{Al}_{3} \mathrm{Ni}$ and oval precipitates of pure aluminum. EBSD maps demonstrated different sizes of nickel grains after the collision with aluminum obtained using the same explosive velocity but various mutual localizations of the clads and their standoff distance. Explosively welded clads were annealed at $500{ }^{\circ} \mathrm{C}$ for $168 \mathrm{~h}$, and as a result of such heat treatment in both types of welds, the following phases were observed: $\mathrm{Al}_{3} \mathrm{Ni}, \mathrm{Al}_{3} \mathrm{Ni}_{2}$ and $\mathrm{Al}_{84} \mathrm{Ni}_{12} \mathrm{Fe}_{4}$ with a similar thickness. As it can be predicted from the equilibrium phase diagram, the first growing phase should be $\mathrm{Al}_{3} \mathrm{Ni}$ and $\mathrm{Al}_{3} \mathrm{Ni}_{2}$ would be the next one. Therefore, it can be presumed that the growth of the $\mathrm{Al}_{3} \mathrm{Ni}_{2}$ phase was at the expense of $\mathrm{Al}_{3} \mathrm{Ni}$. The $\mathrm{Al}_{3} \mathrm{Ni}$ was much thinner even with local discontinuities, where instead of the phase large pores were observed. The applied explosive welding parameters allow obtaining the welds with similar microstructure, wavy interface with the same phase composition, but different melted regions' morphology. The latter ones, however, did not influence the intermetallics' growth velocity and morphology when different mutual arrangements of the flyer and base plates were applied.

\section{Acknowledgements}

The research was co-financed by the European Union from the resources of the European Social Fund (Project No. WND-POWR.03.02.00-00-I043/16).

\section{Compliance with ethical standards}

Conflict of interest The authors declare that they have no conflict of interest.

Open Access This article is licensed under a Creative Commons Attribution 4.0 International License, which permits use, sharing, adaptation, distribution and reproduction in any medium or format, as long as you give appropriate credit to the original author(s) and the source, provide a link to the Creative Commons licence, and indicate if changes were made. The images or other third party material in this article are included in the article's Creative Commons licence, unless indicated otherwise in a credit line to the material. If material is not included in the article's Creative Commons licence and your intended use is not permitted by statutory regulation or exceeds the permitted use, you will need to obtain permission directly from the copyright holder. To view a copy of this licence, visit http://creativecommons.org/licen ses/by/4.0/.

\section{References}

[1] Fronczek DM, Wojewoda-Budka J, Chulist R, Sypien A, Korneva A, Szulc Z, Schell N, Zieba P (2016) Structural 
properties of Ti/Al clads manufactured by explosive welding and annealing. Mater Des 9:80-89

[2] Honarpisheh M, Asemabadi M, Sedighi M (2012) Investigation of annealing treatment on the interfacial properties of explosive-welded $\mathrm{Al} / \mathrm{Cu} / \mathrm{Al}$ multilayer. Mater Des 37:122-127

[3] Saksl K, Ostroushko D, Mazancova E, Szulc Z, Milkovic O, Durisin M, Balga D, Durisin J, Rutt U, Gutowski O (2015) Local structure of explosively welded titanium-stainless steel bimetal. Int J Mater Res 106:621-627

[4] Bina MH, Dehghani F, Salim M (2013) Effect of heat treatment on bonding interface in explosive welded copper/ stainless steel. Mater Des 45:504-509

[5] Acarer M, Demir B (2008) An investigation of mechanical and metallurgical properties of explosive welded aluminumdual phase steel. Mater Lett 62:4158-4160

[6] Kahraman N, Gülenç B, Findik F (2007) Corrosion and mechanical-micro structural aspects of dissimilar joints of Ti-6Al-4V and Al plates. Int J Impact Eng 34:1423-1432

[7] Kahraman N, Gülenç B, Findik F (2005) Joining of titanium/ stainless steel by explosive welding and effect on interface. J Mater Process Technol 169:127-133

[8] Patterson RA (1993) Fundamentals of Explosion Welding. In: Olson DL, Siewert TA, Liu S, Edwards GR (eds) ASM handbook, volume 6: welding, brazing, and soldering. ASM International, Materials Park

[9] Wasek S, Mroz S, Stradomski G, Laber K (2013) The analysis of Al-Cu bimetallic bars bond layers joined by the explosive method. Solid State Phenom 199:508-513

[10] Guo X, Tao J, Wang W, Li H, Chen C (2013) Effects of the inner mould material on the aluminium-316L stainless steel explosive clad pipe. Mater Des 49:116-122

[11] Prazmowski M, Paul H (2012) The effect of stand-off distance on the structure and properties of zirconium - carbon steel bimetal produced by explosion welding. Arch Metall Mater 57:1201-1210

[12] Acarer M, Gulenc B, Findik F (2003) Investigation of explosive welding parameters and their effects on microhardness and shear strength. Mater Des 24:659-664
[13] Crossland B (1982) Explosive welding of metals and its application. Clarendon Press, Oxford, p 233

[14] Blazynski TZ (1983) Explosive welding, forming, and compaction. Elsevier, New York, p 402

[15] Mamalis AG, Szalay A, Vaxevanidis NM, Pantelis DI (1994) Macroscopic and microscopic phenomena of nickel titanium 'shape-memory' bimetallic strips fabricated by explosive cladding and rolling. Mater Sci Eng A 188:267-275

[16] Khoklov VI, Popov GV, Krasnov VD, Andrianov VM (1991) Special features of the change of structure of titanium alloys in explosive welding. Met Sci Heat Treat 32:537-540

[17] Gerland M, Presles HN, Guin JP, Bertheau D (2000) Explosive cladding of thin Ni-film to an aluminium alloy. Mater Sci Eng A280:311-319

[18] Ogneva TS, Lazurenko DV, Bataev IA, Mali VI, Esikov MA, Bataev AA (2016) Formation of intermetallics at the interface of explosively welded $\mathrm{Ni}$-Al multilayered composites during annealing. IOP Conf Ser Mater Sci 124:1-6

[19] Bataev IA, Ogneva TS, Bataev AA, Mali VI, Esikov MA, Lazurenko DV, Guo Y, Jorge Junior AM (2015) Explosive welded multilayer Ni-Al composites. Mater Des 88:1082-1087

[20] Fronczek DM, Chuilst R, Litynska-Dobrzynska L, Lopez GA, Wierzbicka-Miernik A, Schell N, Szulc Z, WojewodaBudka J (2017) Microstructural and phase composition differences across the interfaces in $\mathrm{Al} / \mathrm{Ti} / \mathrm{Al}$ explosively welded clads. Metall Mater Trans A 48A:4154-4165

[21] Wang H, Wang Y (2018) High-velocity impact process: a review. Metals 9:144. https://doi.org/10.3390/met9020144

[22] Crosland B, Williams JD (1970) Explosive welding. Met Rev 15:79-100

[23] Findik F (2011) Recant developments in explosive welding. Mater Des 32:1081-1093

Publisher's Note Springer Nature remains neutral with regard to jurisdictional claims in published maps and institutional affiliations. 